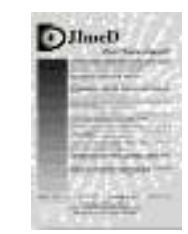

Jurnal Imejing Diagnostik (JImeD) 6 (2020) 28-35

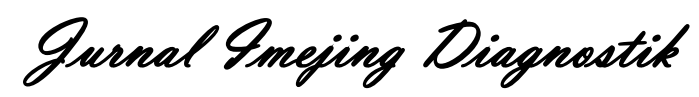

e-ISSN 2621-7457, p-ISSN 2356-301X

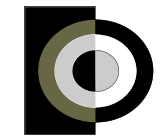

http://ejournal.poltekkes-

smg.ac.id/ojs/index.php/jimed/index

\title{
MSCT Thorax dengan Kasus Efusi Pleura Kanker Paru pada Window Mediastinum post Kontras menggunakan Variasi Nilai Window Width
}

\author{
Tri Puji Hastuti ${ }^{1}$, Yeti Kartikasari ${ }^{2}$, Bagus Abimanyu ${ }^{3}$, Nanang Sulaksono ${ }^{4}$ \\ ${ }^{1}$ RSUD dr. Soehadi Prijonegoro Sragen, Indonesia \\ 2,3,4 Jurusan Teknik Radiodiagnostik dan Radioterapi, Poltekkes Kemenkes Semarang, Indonesia \\ Corresponding author: Tri Puji Hastuti \\ Email: yeti.kartikasari@gmail.com
}

Received: January $30^{\text {th }}, 2020$; Revised: January $31^{\text {th }}, 2020$; Accepted: January $31^{\text {th }}, 2020$

\begin{abstract}
Background: Malignancy of lung cancer is the biggest cause of pleural effusion. To diagnose lung cancer pleural effusion, a thorax MSCT can be examined. The MSCT parameter that affects image contrast is window width. The purpose of this study was to determine the differences in the anatomical information of thorax MSCT images in the post contrast mediastinal window to the use of window width range 350-600 $\mathrm{HU}$ values in cases of lung cancer pleural effusion, and to determine the appropriate window width value to obtain optimal anatomic image information on Thorax MSCT in cases of lung cancer pleural effusion.

Methods: This type of research is quasi experimental. The research was conducted at the Radiology Installation of the Dr. Moewardi Hospital. The data were 60 images of the post contrast mediastinal window thorax MSCT axial slice from 10 patients with 6 window width variations $(350 \mathrm{HU}, 400 \mathrm{HU}, 450 \mathrm{HU}, 500$ $\mathrm{HU}, 550 \mathrm{HU}, 600 \mathrm{HU}$ ). An image assessment was conducted by 3 respondents regarding the resulting of 5 anatomical information. Data analysis used Friedman statistical test.

Results: The results showed that there was a difference in the anatomical information of the thorax MSCT in the post contrast mediastinal window to the window width variation in cases of lung cancer pleural effusion with a significance level of $p$ value $0,000(\rho<0.05)$. Differences in anatomical image information occur in the anatomy of the aorta, limits of pleural effusion with lesions and clarity of lesions, where as there is no difference in anatomy of the right and left primary bronchus. The optimal use of the window width value for thorax MSCT in the post contrast mediastinal window cases of lung cancer pleural effusion is WW 350 HU with a rank value of 4.61 .
\end{abstract}

Conclusions: This study shows that the use of $350 \mathrm{HU}$ window width produces better anatomical image information than the use of other window widths in the case of pleural effusion of lung cancer.

Keyword: MSCT thorax; window mediastinum; window width; efusi pleura; kanker paru

\section{Pendahuluan}

Efusi pleura salah satu kelainan yang ada di thorax. Efusi pleura terjadi karena penumpukan cairan di dalam ruang pleural karena proses penyakit primer dan dapat juga terjadi karena penyakit sekunder akibat penyakit lain. Efusi dapat berupa cairan jernih yang berupa transudat berupa pus atau darah. Menurut Kastelik (2013) efusi pleura merupakan masalah medis dengan insiden tahunan sekitar 1,5 juta di Amerika Serikat.
Keganasan adalah salah satu yang paling sering penyebab efusi pleura. Keterlibatan pleural dapat terjadi hampir semua jenis kanker, dan efusi pleura terlihat pada setengah dari pasien dengan keganasan metastasis. Namun kanker paru merupakan penyebab efusi pleura ganas paling besar sekitar 30\% diikuti oleh kanker-kanker yang lain.

Menurut Webb dkk, (2015) pada pemeriksaan MSCT Thorax penggunaan nilai window width pada window mediastinum adalah 450-500 HU, sedangkan menurut Seeram (2009) 
menggunakan window width $350 \mathrm{HU}$. Menurut penelitian yang dilakukan Joo dkk, (2010) untuk menentukan perbedaan dari malignancy dan benigna pada pericardial effusion dengan pemeriksaan MSCT thorax menggunakan nilai window width $400 \mathrm{HU}$ pada window mediastinum. Penggunaan window width pada pemeriksaan MSCT thorax menurut Arenas dkk (2018) untuk mengevaluasi pasien dengan malignancy pleural effusion pada phase kontras menggunakan nilai window width $400 \mathrm{HU}$. Sedangkan menurut jurnal penelitian yang dilakukan Hierholzer dkk (2000) untuk mendiagnosis penyakit pleura menggunakan nilai window width 350-500 HU dan menurut Raj dkk (2011) MSCT thorax untuk mendiagnosis penyakit pleura dengan membandingkan cara penggunaan media kontras menggunakan parameter window width 400-500 HU pada window mediastinum. Pemeriksaan MSCT Thorax kontras dengan pasien efusi pluera kanker paru sering dijumpai di Instalasi Radiologi RSUD Dr. Moewardi yang menggunakan modalitas MSCT merk Toshiba Aquilion 64 dan dibuat dalam dua tampilan/window yaitu window mediastinum dan lung. Pengaturan parameter window width pada window mediastinum yaitu sebesar $400 \mathrm{HU}$.

Berdasarkan perbedaan penggunaan nilai window width tersebut, peneliti tertarik untuk mengkaji penggunaan variasi window width rentang nilai $350 \mathrm{HU}-600 \mathrm{HU}$ pada window mediastinum post kontras pada kasus efusi pleura kanker paru untuk mengetahui perbedaan informasi citra anatomi dalam penggunaan variasi nilai window width dan mengetahui penggunaan nilai window width yang dapat menghasilkan informasi citra anatomi yang optimal.

\section{Metode}

Jenis penelitian ini adalah penelitian kuantitatif dengan pendekatan eksperimental. Pengambilan data dilakukan pada bulan februari sampai maret 2019. Populasi dan sampel penelitian adalah citra MSCT Thorax window mediastinum post kontras irisan axial terdiri dari 10 pasien dengan menggunakan variasi nilai window width $350 \mathrm{HU}, 400 \mathrm{HU}, 450 \mathrm{HU}, 500 \mathrm{HU}, 550 \mathrm{HU}$ dan $600 \mathrm{HU}$, sehingga didapatkan 60 citra. Pesawat yang digunakan MSCT merk Toshiba Aquilion 64. Metode pengambilan data dengan kuesioner informasi citra anatomi terhadap 3 orang dokter spesialis radiologi.

Data dari hasil responden berupa data ordinal akan diolah dan dianalisa dengan program SPSS 25.
Data tersebut diuji dengan uji kappa untuk mengetahui tingkat persamaan persepsi dari penilaian ketiga responden terhadap variasi nilai window width tersebut. Setelah kesepakatan antar ketiga responden baik maka setelah itu data dianalisa dengan Uji Friedman Test untuk mengetahui perbedaan informasi citra anatomi menggunakan variasi nilai window width tersebut. Penilaian didasarkan pada teori Notoatmodjo (2012), jika $\rho$-value lebih kecil atau sama dengan 0,05 maka Ha diterima dan Ho ditolak, dan untuk informasi citra anatomi manakah yang lebih baik diantara penggunaan variasi nilai window width tersebut penilaian didasarkan dengan melihat Mean Rank.

\section{Hasil dan Pembahasan}

1. Deskriptif Sampel

Tabel 1. Deskripsi Sampel berdasarkan jenis kelamin

\begin{tabular}{ccc}
\hline Jenis Kelamin & Jumlah & Prosentase (\%) \\
\hline Laki-Laki & 7 & $70 \%$ \\
Perempuan & 3 & $30 \%$ \\
\hline TOTAL & $\mathbf{1 0}$ & $\mathbf{1 0 0 \%}$ \\
\hline
\end{tabular}

Berdasarkan tabel tersebut dapat diketahui bahwa dalam penelitian ini menggunakan 10 pasien MSCT Thorax kontras dengan kasus efusi pleura kanker paru dengan presentase laki-laki sebanyak $70 \%$ dan perempuan $30 \%$.

Tabel 2. Deskripsi sampel berdasarkan umur

\begin{tabular}{ccc}
\hline Umur $(\mathbf{T h})$ & Jumlah & Prosentase (\%) \\
\hline$<50$ & 1 & $10 \%$ \\
$50-60$ & 6 & $60 \%$ \\
$>70$ & 3 & $30 \%$ \\
\hline TOTAL & $\mathbf{1 0}$ & $\mathbf{1 0 0 \%}$ \\
\hline
\end{tabular}

Berdasarkan tabel tersebut diketahui penelitian ini menggunakan 10 pasien MSCT Thorax dengan umur dibawah 50 tahun sebanyak 1 (10\%) pasien, dengan rentang umur 50-60 tahun sebanyak $6(60 \%)$ pasien dan umur diatas 70 tahun sebanyak 3 (30\%) pasien.

Tabel 3. Karakteristik Responden

\begin{tabular}{ccc}
\hline Responden & Jabatan & Masa Kerja \\
\hline 1 & $\begin{array}{c}\text { Dokter Spesialis } \\
\text { Radiologi }\end{array}$ & 20 Tahun \\
2 & $\begin{array}{c}\text { Dokter Spesialis } \\
\text { Radiologi } \\
\text { Dokter Spesialis } \\
\text { Radiologi }\end{array}$ & 8 Tahun \\
3 & & \\
&
\end{tabular}


Responden dimohon untuk mengamati dan mengisi kuesioner dengan form cek list sesuai dengan kriteria anatomi yang dinilai yaitu kejelasan dari anatomi bronchus priamarius kanan, bronchus primarius kiri, aorta, kejelasan batas cairan efusi pleura dengan lesi dan kejelasan lesi. Masing-masing dokter spesialis radiologi memberikan penilaian terhadap citra MSCT Thorax pada window mediastinum post kontras dari 10 pasien dengan 6 variasi nilai window width yang digunakan, sehingga citra yang dinilai masing-masing responden adalah sebanyak 60 citra.

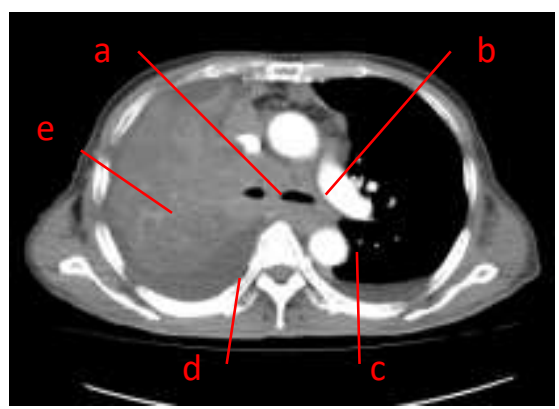

Gambar 1. Anatomi MSCT thorax irisan axial pada window mediastinum post kontras yang akan dinilai responden yaitu bronchus primarius kanan (a), bronchus primarius kiri (b), aorta (c), batas caitan efusi pleura dengan lesi (d) dan kejelasan lesi (e).

Berikut ini hasil citra pemeriksaan MSCT thorax dengan kasus efusi pleura kanker paru pada window mediastinum post kontras dengan variasi window width, ditunjukkan pada gambar 2 dibawah ini :
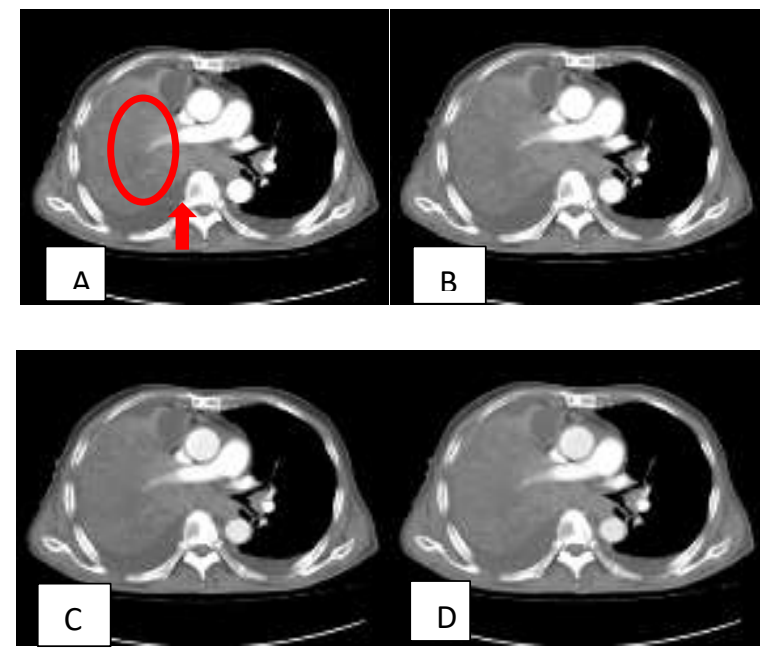

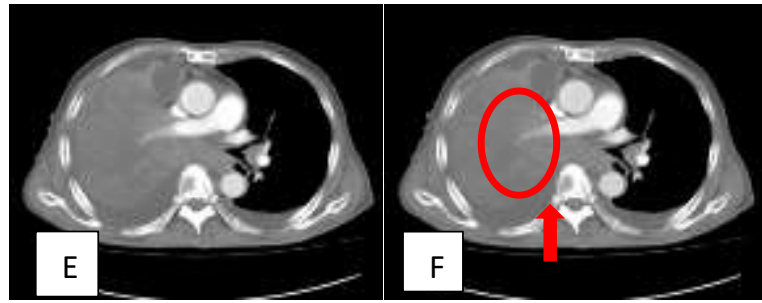

Gambar 4.2 Hasil citra MSCT thorax pada window mediastinum post kontras dengan penggunaan variasi nilai window width $350 \mathrm{HU}(\mathrm{A})$, window width 400 (B), window width $450 \mathrm{HU}(\mathrm{C})$, window width $500 \mathrm{HU}(\mathrm{D})$, window width $550 \mathrm{HU}$ (E) dan window width $600 \mathrm{HU}(\mathrm{F})$. Tanda panah merah adalah cairan efusi dan tanda lingkaran merah adalah lesi

2. Hasil Pengujian Perbedaan Informasi Citra Anatomi MSCT Thorax dengan Kasus Efusi Pleura Kanker Paru pada Window Mediastinum Post Kontras Menggunakan Variasi Nilai Window Width

Pengujian dengan cara penilaian menggunakan kuesioner oleh 3 dokter spesialis radiologi dengan skor 4 berarti "sangat jelas" diberikan apabila citra anatomi bronchus primarius kanan dan kiri, aorta, batas cairan efusi pleura dengan lesi, dan lesi citranya tampak sangat tinggi, mudah dilihat dan berbatas tegas, skor 3 berarti "jelas" diberikan apabila citra anatomi bronchus primarius kanan dan kiri, aorta, batas cairan efusi pleura dengan lesi, dan lesi citranya tampak tinggi, mudah dilihat, namun tidak berbatas tegas, skor 2 berarti "kurang jelas" diberikan apabila citra anatomi bronchus primarius kanan dan kiri, aorta, batas cairan efusi pleura dengan lesi, dan lesi citranya tampak cukup, batasnya tidak terlalu tampak oleh mata observer, dan skor 1 berarti "tidak jelas" diberikan apabila citra anatomi bronchus primarius kanan dan kiri, aorta, batas cairan efusi pleura dengan lesi, dan lesi citranya rendah, batasnya tidak jelas bahkan responden sulit menemukan informasi yang dimaksud pada citra yang diamati.

Uji yang digunakan untuk mengetahui tingkat reabilitas (persamaan persepsi) dari penilaian ketiga responden terhadap penggunaan variasi nilai window width tersebut menggunakan uji Cohen's Kappa. 
Tabel 4. Hasil Uji Cohen's Kappa

\begin{tabular}{ccl}
\hline Responden & $\begin{array}{c}\text { Koefisien } \\
\text { reabilitas }(\mathbf{r})\end{array}$ & \multicolumn{1}{c}{ Keterangan } \\
\hline $\mathrm{R} 1 * \mathrm{R} 2$ & 0,746 & Kesepakatan kuat \\
$\mathrm{R} 1 * \mathrm{R} 3$ & 0,452 & Kesepakatan cukup \\
$\mathrm{R} 2 * \mathrm{R} 3$ & 0,587 & Kesepakatan cukup \\
\hline
\end{tabular}

Berdasarkan hasil uji cohen's kappa pada tabel diatas tingkat kesepakatan dari ketiga responden nilai tingkat kesepakatan paling tinggi ada pada responden 1 dengan responden 2 dengan hasil 0,746. Menurut Dahlan (2015), nilai koefisien realibilitas $(\mathrm{r})$ antara 0,61 hingga 0,80 menunjukkan tingkat kesepakatan kuat.

Nilai reabilitas atau tingkat persamaan persepsi antar responden menunjukkan tingkat kesepakatan kuat, selanjutnya dilakukan pemilihan data responden yang akan dilakukan Uji Friedman Test berdasarkan dengan melihat nilai kesepakatan yang tinggi dan lamanya bekerja yaitu responden 1 dengan lama bekerja 20 tahun dan merupakan dokter spesialis radiologi konsulen thorax. Uji friedman test digunakan dalam penelitian ini karena data penelitian ini adalah data non parametrik ordinal dengan lebih dari dua kelompok (k sampel). Hasil pengujian perbedaan informasi citra anatomi MSCT Thorax dengan kasus efusi pleura kanker paru pada window mediastinum post kontras menggunakan variasi nilai window width, sebagai berikut :

Tabel 5. Hasil Uji Friedman Test Informasi Anatomi setiap Bagian dengan Penggunaan Variasi Nilai Window Width

\begin{tabular}{clcl}
\hline No & \multicolumn{1}{c}{ Anatomi } & $\boldsymbol{\rho}$ value & \multicolumn{1}{c}{ Arti } \\
\hline 1 & Bronchus & 0,075 & Tidak Ada \\
& primarius kanan & & $\begin{array}{l}\text { Beda } \\
2\end{array}$ \\
& $\begin{array}{l}\text { Bronchus } \\
\text { primarius kiri }\end{array}$ & 0,059 & $\begin{array}{l}\text { Tidak Ada } \\
\text { Beda }\end{array}$ \\
3 & Aorta & 0,001 & Ada Beda \\
4 & $\begin{array}{l}\text { Batas cairan efusi } \\
\text { pleura dengan lesi }\end{array}$ & 0,000 & Ada Beda \\
5 & Lesi & 0,000 & Ada Beda \\
\hline
\end{tabular}

Berdasarkan tabel hasil uji friedman test diatas didapatkan hasil informasi anatomi pada organ bronchus primarius kanan diperoleh nilai $\rho$ value sebesar $0,075 \quad(\rho>0,05)$, hal ini menunjukkan tidak ada beda pada organ bronchus primarius kanan pada setiap variasi nilai window width, pada organ bronchus primarius kiri diperoleh nilai $\rho$ value sebesar $0,059(\rho>0,05)$ hal ini menunjukkan tidak ada beda pada bronchus primarius kiri pada setiap variasi nilai window width. Pada anatomi aorta didapatkan nilai $\rho$ value sebesar $0,001(\rho<0,05)$, hal ini menunjukkan ada beda kejelasan dari aorta dengan penggunaan variasi nilai window width, sedangkan pada batas cairan efusi pleura dengan lesi terdapat perbedaan kejelasan batas cairan efusi pleura dengan lesi pada penggunaan variasi nilai window width yang ditunjukkan dengan besarnya nilai $\rho$ value $=0,000(\rho<0,05)$. Pada kejelasan lesi diperoleh nilai $\rho$ value sebesar $0,000(\rho<0,05)$, menunjukkan adanya perbedaan kejelasan lesi pada penggunaan variasi nilai window width.

Tabel 6. Hasil Uji Friedman Test Perbedaan Informasi Citra Anatomi secara Keseluruhan pada Penggunaan Variasi Nilai Window Width

\begin{tabular}{ccc}
\hline Nilai Variasi & $\rho$ value & Keterangan \\
Window Width & & \\
\hline $350 \mathrm{HU}$ & & \\
$400 \mathrm{HU}$ & & \\
$450 \mathrm{HU}$ & & \\
$500 \mathrm{HU}$ & 0,000 & Ada Beda \\
$550 \mathrm{HU}$ & & \\
$600 \mathrm{HU}$ & & \\
\hline
\end{tabular}

Berdasarkan hasil uji statistik non parametrik friedman test diatas menunjukkan nilai signifikansi $\rho$ value $=0,000(\rho<0,05)$, yang artinya H0 ditolak dan $\mathrm{Ha}$ diterima, menunjukkan adanya perbedaan yang signifikan pada informasi citra anatomi dengan penggunaan variasi nilai window width rentang 350-600 HU pada pemeriksaan MSCT thorax irisan axial dengan kasus efusi pleura kanker paru pada window mediastinum post kontras.

Kualitas citra dalam MSCT harus dapat memperlihatkan gambaran anatomi yang sesuai dan dapat memberikan nilai akurasi diagnostik yang tinggi, salah satu parameter MSCT yang mempengaruhi kontras citra anatomi MSCT adalah penggunaan nilai window width. Menurut Seeram (2009) semakin tinggi window width yang digunakan maka gambar akan 
terlihat semakin kurang kontras, Hal ini disebabkan pada 3 struktur tubuh yaitu paru (udara), hepar (soft tissue), dan pelvis (bone) berada pada tingkat keabuan/grayscale yang sama, sebaliknya semakin rendah window width yang digunakan kontras gambar yang dihasilkan akan semakin tajam (gambar terlihat hitam dan putih), sehingga dengan pemilihan window width yang tepat, diharapkan gambar MSCT yang dihasilkan dapat memberikan informasi diagnostik yang dapat menampilkan informasi anatomi yang optimal.

Berdasarkan hasil statistik non parametrik uji friedman test pada penelitian ini menunjukkan nilai signifikan $\rho$ value $=0,000(\rho<0,05)$ artinya Ho ditolak dan $\mathrm{Ha}$ diterima, sehingga menunjukkan adanya perbedaan yang signifikan pada informasi citra anatomi pada penggunaan variasi nilai window width pada pemeriksaan MSCT thorax irisan axial window mediastinum post kontras, namun hasil uji friedman test pada informasi citra pada setiap kriteria anatomi terdapat beberapa organ yang tidak ada beda yaitu pada anatomi bronchus primarius kanan dan bronchus primarius kiri.

\section{a. Bronchus Primarius Kanan dan Kiri}

Dari uji friedman test kriteria anatomi bronchus primarius kanan dan kiri dari pengaturan window width 350-600 HU didapatkan nilai $\rho$ value 0,075 dan $0,059 \quad(\rho>0,05)$ hal ini menunjukkan tidak ada perbedaan kontras citra yang dihasilkan dari penggunaan variasi nilai window width pada anatomi bronchus primarius kanan dan kiri.

Menurut peneliti anatomi bronchus primarius kanan dan kiri memiliki kontras gambar yang sama dari enam variasi window width karena bronchus primarius merupakan bagian dari rongga yang berisi udara sehingga tampilan dalam citra hitam, dan kejelasan anatomi bronchus primarius kanan dan kiri tidak dipengaruhi oleh variasi nilai window width tetapi kejelasan bronchus primarius kanan dan kiri tergantung dari letak dan ukuran dari lesi yang ada didaerah thorax yang dapat mendesak bronchus primarius dan tergantung stadium dari kanker paru.

Sesuai jurnal penelitian Detterbeck (2017) tentang klasifikasi stadium kanker yaitu didapatkan bahwa pada stadium 4 sel kanker sudah metastase pada daerah trachea sampai bronchus sehingga bronchus primarius terdesak oleh lesi, sehingga kejelasan bronchus primarius tidak terpengaruh oleh pengaturan nilai window width.

\section{b. Aorta}

Dari uji friedman test kriteria anatomi aorta dari penggunaan variasi nilai window width $350-600$ HU didapatkan nilai $\rho$ value $0,001(\rho<0,05)$ dan hasil prosentase penilaian deskriptif responden berdasarkan tabulasi diperoleh jawaban responden "sangat jelas" pada penggunaan window width 350 dan mendominasi dari pada window width yang lain.

Menurut peneliti dari penggunaan variasi nilai window width tersebut ada beda dikarenakan citra yang dihasilkan pada penggunaan window width $350 \mathrm{HU}$ lebih hiperdens dibagian aorta dibandingkan dengan citra yang dihasilkan pada penggunaan window width yang lain.

Sesuai teori Bontrager dkk (2018) bahwa sistem vaskuler atau pembuluh darah yang semula penampakannya abu-abu setelah dikasih media kontras dapat menjadi putih tampilannya, dan menurut Seeram (2009) bahwa semakin turun nilai window width yang digunakan maka semakin tajam kontrasnya sehingga citra anatomi aorta pada window width $350 \mathrm{HU}$ tampilannya lebih putih.

\section{c. Batas Cairan Efusi Pleura dengan Lesi}

Dari uji friedman test kriteria batas cairan efusi pleura dengan lesi dari penggunaan variasi nilai window width 350-600 HU didapatkan nilai $\rho$ value $0,000 \quad(\rho<0,05)$ dan hasil prosentase penilaian deskriptif responden berdasarkan tabulasi diperoleh jawaban responden "sangat 
jelas" pada penggunaan window width 350 dan mendominasi daripada window width yang lain.

Menurut peneliti dari penggunaan variasi nilai window width tersebut ada beda dikarenakan citra yang dihasilkan pada penggunaan window width $350 \mathrm{HU}$ kontras gambar terlihat jelas dan lebih tegas dibagian batas cairan efusi pleura dengan lesi dibandingkan dengan citra yang dihasilkan pada penggunaan window width yang lain.

Menurut Seeram (2009) window width mempengaruhi kontras gambar, semakin tinggi nilai window width (400-2000 HU) yang digunakan maka kontras gambar akan menurun dan anatomi organ akan semakin tidak terlihat jelas. Sebaliknya semakin rendah window width (50-350 HU) yang digunakan maka kontras gambar akan naik dan anatomi organ akan terlihat total hitam pada paru-paru dan putih pada tulang. Sehingga pengaturan window width pada penelitian ini terbukti dimana semakin tinggi akan memperlihatkan informasi anatomi semakin kurang dimana gambaran batas efusi pleura dengan lesi semakin terlihat tidak jelas dan tidak tegas batasnya.

\section{d. Lesi}

Dari uji friedman test kriteria kejelasan dari lesi pada penggunaan variasi nilai window width 350-600 HU didapatkan nilai $\rho$ value 0,000 $(\rho<0,05)$ dan hasil prosentase penilaian deskriptif responden berdasarkan tabulasi diperoleh jawaban responden "sangat jelas" pada penggunaan window width 350 dan mendominasi daripada window width yang lain.

Menurut peneliti dari penggunaan variasi nilai window width tersebut ada beda dikarenakan citra yang dihasilkan pada penggunaan window width $350 \mathrm{HU}$ kontras gambar terlihat optimal dan lebih tegas pada bagian lesi dibandingkan dengan citra yang dihasilkan pada penggunaan window width yang lain, hal ini karena nilai CT number dari soft tissue adalah +100 sampai +300 HU sehingga tampilan pada citra MSCT dikonversikan menjadi scala abu-abu pada nilai window width sekitar $300 \mathrm{HU}$, sehingga citra dari lesi tampak enhance (tajam) pada window width $350 \mathrm{HU}$ dibandingkan dengan window width diatas $350 \mathrm{HU}$.

Hal ini sesuai dengan teori (Seeram, 2009) bahwa semakin tinggi nilai window width yang digunakan maka kontras gambar yang dihasilkan akan turun, sebaliknya semakin rendah nilai window width yang digunakan maka citra gambar yang dihasilkan lebih tajam kontrasnya. Sehingga pengaturan window width pada penelitian ini terbukti dimana semakin tinggi akan memperlihatkan informasi anatomi semakin kurang dimana gambaran lesi semakin terlihat tidak jelas dan tidak tegas batasnya.

3. Nilai Window Width pada Window Mediastinum Post Kontras yang Tepat untuk Mendapatkan Informasi Citra Anatomi yang Optimal pada MSCT Thorax Kasus Efusi Pleura Kanker Paru

Tabel 7. Hasil Mean Rank Uji Statistik Friedman Test Keseluruhan Informasi Citra Anatomi pada Penggunaan Variasi Nilai Window Width

\begin{tabular}{cc}
\hline Variasi Window Width & Mean Rank \\
\hline $350 \mathrm{HU}$ & 4,61 \\
$400 \mathrm{HU}$ & 4,32 \\
$450 \mathrm{HU}$ & 3,35 \\
$500 \mathrm{HU}$ & 3,08 \\
$550 \mathrm{HU}$ & 2,88 \\
$600 \mathrm{HU}$ & 2,76 \\
\hline
\end{tabular}

Berdasarkan tabel 7. hasil nilai mean rank pada uji friedman test keseluruhan anatomi pada penggunaan variasi nilai window width pada pemeriksaan MSCT thorax kasus efusi pleura kanker paru pada irisan axial window mediastinum post kontras menunjukkan bahwa nilai window width $350 \mathrm{HU}$ merupakan nilai mean rank tertinggi yaitu 4,61 . Sedangkan nilai window width dengan nilai mean rank terendah pada window width $600 \mathrm{HU}$ yaitu dengan nilai mean rank 2,76. Hal ini menunjukkan bahwa nilai window width $350 \mathrm{HU}$ pada pemeriksaan MSCT thorax pada window mediastinum post kontras menghasilkan informasi citra anatomi yang lebih optimal dari pada nilai window width yang lain. 
anatomi menunjukkan bahwa anatomi bronchus primarius kanan pada penggunaan nilai window width $350-500 \mathrm{HU}$ memiliki nilai mean rank yang lebih tinggi yaitu 3,70. Pada anatomi brochus primarius kiri pada penggunaan nilai window width 350-400 HU memiliki nilai mean rank yang lebih tinggi yaitu 3,90. Pada anatomi aorta nilai mean rank tertinggi pada penggunaan window width 350 HU yaitu sebesar 4,85 dibandingkan dengan penggunaan window width yang lainnya. Sedangkan pada kejelasan batas cairan efusi pleura dengan lesi, nilai mean rank tertinggi yaitu sebesar 5,30 pada penggunaan window width $350 \mathrm{HU}$, sebaliknya nilai mean rank terendah yaitu 2,15 pada window width $600 \mathrm{HU}$ dan pada kejelasan lesi, nilai mean rank tertinggi yaitu sebesar 5,35 pada penggunaan window width $350 \mathrm{HU}$, sedangkan nilai mean rank terendah yaitu 2,35 pada penggunaan nilai window width $600 \mathrm{HU}$. Dengan perolehan nilai mean rank tersebut diatas menunjukkan bahwa penggunaan window width $350 \mathrm{HU}$ memiliki nilai maen rank yang lebih tinggi pada seluruh kriteria anatomi.

Berdasarkan nilai mean rank pada uji friedman test keseluruhan anatomi pada penggunaan nilai window width $350 \mathrm{HU}, 400$ HU, $450 \mathrm{HU}, 500 \mathrm{HU}, 550 \mathrm{HU}$ dan $600 \mathrm{HU}$ pada pemeriksaan MSCT Thorax kasus efusi pleura kanker paru pada irisan axial window mediastinum post kontras pada penggunaan nilai window width $350 \mathrm{HU}$ diperoleh nilai mean rank tertinggi yaitu 4,61 sedangkan nilai mean rank terendah pada penggunaan window width 600 HU yaitu sebesar 2,76. Hal ini menunjukkan bahwa window width $350 \mathrm{HU}$ pada pemeriksaan MSCT thorax kasus efusi pleura kanker paru pada irisan axial window mediastinum post kontras menghasilkan informasi citra anatomi yang lebih baik daripada penggunaan window width yang lain.

Menurut peneliti, penggunaan nilai window width $350 \mathrm{HU}$ pada kasus efusi pleura kanker paru memperlihatkan kontras gambar yang optimal sehingga gambaran yang dihasilkan dapat jelas dan batas cairan efusi pleura dengan lesi sangat tegas, hal ini dikarenakan nilai CT number dari soft tissue adalah +100 sampai +300 HU sehingga tampilan pada citra MSCT dikonversikan menjadi skala abu-abu pada nilai window width sekitar $300 \mathrm{HU}$, sehingga citra dari lesi tampak enhance (tajam) pada window width $350 \mathrm{HU}$ dibandingkan dengan window width diatas $350 \mathrm{HU}$. Hal ini sesuai dengan teori Seeram (2009) bahwa untuk scanning daerah tubuh dan daerah thorax menggunakan nilai window width 350-600 HU pada window mediastinum untuk menampakkan atenuasi CT number dari lemak, cairan, jaringan lunak dan otot, dan dengan penggunaan nilai window width tinggi yaitu 600 terbukti menurunkan kontras gambar dan sebaliknya dengan menggunakan nilai window width $350 \mathrm{HU}$ terbukti memberikan kontras gambar yang lebih baik dari window width $600 \mathrm{HU}$.

Pada penelitian ini penggunaan variasi nilai window width 350-600 HU sama-sama mampu untuk menampakkan informasi anatomi pemeriksaan MSCT thorax dengan kasus efusi pleura kanker paru pada window mediastinum post kontras irisan axial. Di Instalasi Radiologi RSUD dr. Moewardi menggunakan nilai window width $400 \mathrm{HU}$, dan nilai window width $400 \mathrm{HU}$ dalam penelitian ini juga memberikan nilai kontras gambar yang baik karena merupakan maen rank peringkat ke dua. Akan tetapi penggunaan nilai window width $350 \mathrm{HU}$ yang merupakan maen rank tertinggi dapat memberikan nilai kontras gambar yang optimal dan baik sehingga dapat menampakkan informasi citra anatomi lebih baik secara subjektif pengamat (responden).

\section{Simpulan}

Berdasarkan hasil penelitian dan pembahasan dapat disimpulkan bahwa terdapat perbedaan informasi citra anatomi yang signifikan pada penggunaan variasi nilai window width dengan tingkat signifikansi $\rho$ value $=0,000(\rho<0,05)$ yang artinya adanya perbedaan yang signifikan pada keseluruhan informasi citra anatomi MSCT thorax dengan kasus efusi pleura kanker paru pada window mediastinum post kontras dengan penggunaan variasi nilai window width, namun pada informasi 
citra pada tiap kriteria anatomi terdapat beberapa organ yang tidak ada beda yaitu pada organ bronchus primarius kanan dengan $\rho$ value 0,075 $(\rho>0,05)$, dan bronchus primarius kiri dengan $\rho$ value $0,059(\rho>0,05)$, sedangkan pada organ aorta terdapat perbedaan informasi citra anatomi dengan $\rho$ value $0,001(\rho<0,05)$ dan pada kejelasan batas cairan efusi pleura dengan lesi dan kejelasan lesi juga terdapat perbedaan informasi citra anatomi dengan $\rho$ value $0,000(\rho<0,05)$.

Nilai mean rank pada penggunaan nilai window width $350 \mathrm{HU}$ lebih tinggi dibandingkan penggunaan nilai window width yang lain pada keseluruhan informasi citra anatomi dengan nilai mean rank pada window width $350 \mathrm{HU}$ adalah 4,61, maka dengan ini menunjukkan bahwa penggunaan window width $350 \mathrm{HU}$ menghasilkan informasi citra anatomi lebih baik dibandingkan dengan penggunaan window width lain pada kasus efusi pleura kanker paru.

\section{Daftar Pustaka}

Arenas-Jimenez JJ, Garcia-Garrigos E, EscuderoFresneda C, Sirera-Matilla M, Garcia-Pastor, et al. 2018. Early and delayed phase of contrastenhanced CT for evaluating patients with malignant pleural effusion.Result of pairwise comparison by multiple observers: www. birpublications.org.

Bontrager, Kenneth L. 2001. Textbook of Positioning and Related Anatomy, Fifth Edition. CV. Mosby Company. St. Louis.

Dahlan, M.S. 2015. Statistik Untuk Kedokteran dan Kesehatan. Jakarta: Epidemiologi Indonesia (Pstat-Consulting).

Detterbeck MD, Frank C. 2007. The eighth edition TNM stage classification for lung cancer: What does it mean on main street? https://doi.org/10.1016/j.jtcvs.2017.08.138

Hierholzer, Johannes, Liangping, et al. 2000. MRI and CT in the Differential Diagnosis of Pleural Disease: www.nursing\&alliadhealthdatabase.com.

Joo, Sung Suu. Kyung, Joo Park. Doo, Kyoung Kang. 2010. CT Findings in Patients With Pericardial Effusion: Differentiation of Malignant and Benign Disease : www.ajronline.org.

Kastelik, JA. 2013. Management of Malignant Pleural Effusion. www.ajronline.org.

Notoatmodjo, S. 2012. Metodologi Penelitian Kesehatan. Jakarta: PT Asdi Mahasatya.

Raj, V. R, kirke, et al. 2011. Multidetector CT imaging of pleura: comparison of two contrast infusion protocols: www.ajr.org.

Seeram, Euclid. 2009. Computed Tomography: Physical Principles, Clinical Applications, and Quality
Control. Third Edition. W. B. Saunders Company. Philladelphia.

Snell, Richard. S . 2012. Clinical Anatomy By Regions. Ninth edition. Lippincot Williams \& Wilkins, Philadelphia.

Webb, W. Richard. William, E Brant. Nancy, M. Major. 2015. Fundamental of Body CT. Fourth Edition. Saunders Company, Philadelphia 